REVISTA DE LITERATURA E CULTURA RUSSA

Концепт „лишние люди"

и его динамика в русской драматургии XIX века

The concept of "superfluous people" and its dynamics in Russian drama of the XIX century

Autor: Людмил Димитров Edição: RUS Vol. 11. № 16 Data: Setembro 2020 


\section{Концепт „лишние люди“ и его динамика в русской
драматургии XIX века}

Людмил Димитров*

\author{
Аннотация: Понятие «лишние люди» \\ возникло в русской литературе в \\ 1850-ые годы и постепенно было \\ перенесено во внелитературную \\ среду, став идеологемой. В статье \\ предпринята попытка исследовать \\ этот феномен в пространстве \\ русской драматургии, начиная с \\ Грибоедова и вплоть до драматургов \\ конца XIX - начала XX века - \\ Льва Толстого, Антона Чехова и \\ Максима Горького, представителей \\ трех разных поколений, а также \\ трех эстетических направлений \\ социокультурной мысли в России, \\ которые оказали огромное влияние \\ на развитие европейского театра в \\ XX и XXI века.
}
Abstract: The concept of "superfluous men" arose in Russian literature in the 1850 s and was gradually transferred to the non-literary environment, becoming an ideologeme. This article attempts to explore its appearance in Russian dramaturgy, beginning with Griboedov and into the late 19th and early 20th century in the work of playwrights Leo Tolstoy, Anton Chekhov and Maxim Gorky, representatives of three different generations and also three aesthetic orientations in the socio-cultural thought in Russia that exercised a great influence on the development of the European theater in the 19th and 20th century.

Ключевые слова: «Лишний человек»; Русская драматургия; Социальная реформа; Идеология; Эстетика Keywords: "Superfluous man"; Russian dramaturgy; Social reform; Ideology; Aesthetics 
* Людмил Димитров - доктор филологических наук, профессор Кафедры русской литературы Софийского университета им. Св. Климента Охридского, Болгария; https:// orcid.org/0000-0003-4672-1519; ljudiv@abv.bg
Иванов: Я умираю от стыда при мысли, что я, здоровый, сильный человек, обратился не то в Гамлета, не то в Манфреда, не то в лишние люди... сам черт не разберет! Есть жалкие люди, которым льстит, когда их называют Гамлетами или лишними, но для меня это - позор! Чехов, „Иванов“ (1887)

Федя: Ну так слушай, Саша. Правда, что я муж, отец ее ребенка, но я лишний. Толстой, „Живой труп“ (1900)

Настя: Надоело мне... Лишняя я здесь... Бубнов (спокойно): Ты везде лишняя... да и все люди на земле - лишние... Горький, „На дне“ (1902)

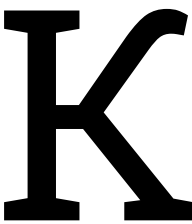

онцепт „лишние люди“ в русской литературе возник в 50-е годы XIX века и постепенно был перенесен (наложен) на социально-политическую ситуацию, для которой он оказался весьма подходящим и устойчивым; точнее, вырвавшись из породившей его высокого, литературного контекста, он прочно „поселился“ / стал бытовать в чужеродной для него среде, оставаясь связанным со своим художественным генезисом. В этом смысле он оказался некоей инверсией по отношению к сюжетопорождающим стереотипам, проникшим в литературу через экзистенциальные ситуации - форманты русского медитативного общения (преимущественно в аристократических кругах): чаепития, игру в карты или очень распространенную в классическую эпоху практику дуэлей. С другой стороны, номинация постепенно стала охватывать все более разрастающие- 
ся общественые явления и рецидивы, из которых самыми популярными были мертвые души, „обломовщина“1 (апатия, скука, слабохарактерность, отсутствие любого интереса к жизни), человек в футляре и в нередких случаях - непредсказуемое двойственное поведение интеллигенции: той прослойки, признаваемой как „чисто русский морально-этический феномен“, по словам писателя и публициста Петра Боборыкина, провозгласившего себя ее крестным отцом. Основания для подобного самовыдвижения он видел не в том, что придумал само понятие, ${ }^{2}$ а в том, что он первый, кто придал ему социальный статус. Я намеренно обращаю внимание на эту подробность, поскольку все компоненты парадигмы легко поддаются идеологизации, более того, русская нация не просто зародилась в литературе (и является литературоцентричной), но так же активно практиковала мифотворчество, что привело к освобождению элементов системы и позволила им зажить самостоятельно именно как идеологемы (идеологические клише).

Независимо от того, кто и с какой целью открыл / дал определение интеллигенции, с уверенностью можно сказать, что крестным отцом исследуемого в этом тексте явления, хотя и бессознательно, стал И. С. Тургенев. Впервые это устойчивое словосочетание появилось в заглавии его короткой повести „Дневник лишнего человека“, вышедшей как раз в середине века (1850 г.). В повести рассказана история персонажа по фамилии Чулкатурин (его собственное имя и отчество не упоминаются), господина лет тридцати, бедного, страдающего чахоткой и описывающего свою безрадостную судьбу, на которой лежит печать не только и не столько болезни, сколько его несчастной влюбленности в Лизу, дочь

\footnotetext{
1 По имени главного героя одноименного романа И. А. Гончарова „Обломов“ (1859).

2 Еще в 1836 г. Василий Жуковский пишет в своем дневнике: „...потянулись кареты, все наполненные лучшим петербургским дворянством, тем, которое у нас представляет всю русскую европейскую интеллигенцию“. В сущности, заслуга Боборыкина в том, что тогда как до него понятие употребляется как чужое (немецкое) заимствование, он его русифицирует, и таким образом его начинают воспринимать на Западе как специфический русский термин.
} 
влиятельного провинциального чиновника, которая нашему герою предпочла молодого изысканного князя Н. Дневниковая „я“-форма предполагает интимную исповедь, самоанализ с уничижительными и нелицеприятными подробностями, в данном случае в большей степени обвиняющий себя, нежели обвинительный по отношению к другим. В сущности, Чулкатурин - н е начало, а один из этапов деградации лишнего человека, что видно по нарастающему отсутствию воли, отказу бороться и защищать свою любовь, по обиде, отчаянию, примирению и добровольной самоизоляции.

В более глобальном аспекте, серьезность проблемы заключается еще и в том, что она была замечена извне - Тургенев не только пишет свою повесть за границей, но и наблюдает за Россией на расстоянии, констатируя факты, которые жители метрополии с большим трудом замечают и незаметно для себя подчиняются навязанным внутриполитическим „консенснусным“ манипуляциям. Интересно, что Тургенев идет дальше по пути к осознанию своего собственного открытия: он первым формулирует и берется выяснить (в своей одноименной статье 1859 г.) проблему „Гамлет и Дон Кихот“, рассматривая два поведенческих начала не в контексте взаимного отрицания (активность / пассивность), а как естественным образом дополняющие друг друга черты, как динамическую конструкцию, в которой один элемент периодически берет вверх над другим. По мнению автора, русскому человеку в значительной степени ближе и более присущ гамлетизм (философствование, провидение, аналитизм, умозрительная инертность), чем донкихотство (действие), и именно это колебание, эта нерешительность в конечном счете приводит к его „Излишности" / „ненужности“. И снова возвращаясь к Тургеневу, к его известной повести „Ася“ (1858), хочется вспомнить вот что: в своем этюде „Литературный тип слабого человека" (1858) П. В. Анненков среди прочего обращается к анализу этого произведения и направляет намеченное и отмеченное в тексте явление в поле 
социологии, во многом опираясь на Герцена, в статье которого „Лишние люди и желчевики“ (1860) в художественном явлении усматриваются уже идеологические мотивы. Иными словами, ровно за одно десятилетие, отделяющее „дневниковую“ повесть Тургенева от статьи Герцена, понятие приобрело новую семантику и из безобидной (хотя и эффектной) литературной метафоры превратилось в социально-политическую, иногда употребляемую в буквальном смысле. По мнению автора „Кто виноват?", к „лишним людям“ „принадлежат на первом плане раскольники и декабристы, а потом всем западники и восточники, Онегины и Ленские [...] - все они, как ветхозаветные пророки, были вместе протестом и надеждой" (Герцен: электронная версия). Тем не менее, мы не должны забывать, что описанная трансформация - достаточно поздний факт: тип „лишнего человека" появляется уже в 20-е - 30-е годы XIX века, первоначально в сильно индивидуализованном „байроническом" варианте: это (сверх)человек, романтик, безразличный к своей среде, но осознающий свое превосходство над ней, с „преждевременной старостью души" (Пушкин), усталый, скептически настроенный и отчаянный. Исторически такой типаж был представлен не только Онегиным, но и следующими за ним Печориным, Бельтовым, Рудиным, Лаврецким... И только в 60-е - 70-е годы данный тип был обоснован как массовый и проявил завидную жизнестойкость вплоть до наступления большевизма, когда растворился в массе пролетаризующегося-люмпенизующегося классового общества и исчез с повестки как несостоятельный.

Поскольку, однако, речь идет о явлении, возникшем в русской литературе в ее золотой век, далее в изложении я попробую вписать его в более широкий культурный контекст; иначе говоря, меня интересует вопрос, как реагирует на него драматургия - интересен ли он для перформативного показа и берется ли театр „раструбить" его / подвергнуть общественному дебату со своей собственной „колокольни“ - сцены. Драматургия - и это 
особенно важно! - естественная эстетическая рамка русского фикционального себевыражения в интересующий нас период: XIX век начинается с пьесы (комедии) "Горе от ума" А. С. Грибоедова (1824) и заканчивается комедией „Вишневый сад“ А. П. Чехова, недвусмысленно демонстрируя не только диалогичность, но и духовную рефлексивность русского человека - признание другого как действительного субъекта, желание делиться чувствами и мыслями и осознавать себя в процессе общения с ним, обсуждать, спорить, убеждать его, овладевать им, подчинять его, помогать ему. Именно драматургия - та модульная структура, которая удерживает русский мир в кажущейся целостности, если вспомнить грустную констатацию Гамлета о „распавшейся связи времен" и „разваливщемся глобусе“-мире в конце его „собственого“ первого действия. В литературном смысле век начинается позже своего хронологического начала (только в 20-е годы) и кончается чуть позже своего формального конца - в 1904, когда в окончательном виде выходит последняя пьеса Чехова и когда через несколько месяцев умирает сам Чехов.

Именно драматургия создает первое значимое каноническое произведение с „лишним“ героем, чьей основной характеристикой, до того, как превратиться в массового (и „бывшего“, по словам Горького) человека, была не только способность бунтовать, не соглашаться, но и необходимость активно сопротивляться. Собственно говоря, с момента приезда в дом Фамусова после трехлетнего отсутствия в Москве Чацкий сразу чувствует себя лишним, но долгое время пытается понять, что именно послужило этому причиной, чья в том вина. Словом, герой проявявляет неистовую настойчивость остаться в среде, которая почти сразу дает ему понять, что она не считает его своим и не желает его присутствия. И так как в своих в действиях он не просто ограничен обстоятельствами, а встречает сопротивление среды (так, в стремлении быть Дон Кихотом, ему по неволе приходится стать Гамлетом), Чацкий пытается 
достучаться до окружающих своими вызывающими выступлениями-монологами. Софья, в чей дом „чуть свет" заходит наш герой, даже перед тем, как заехать к себе, - это его возлюбленная, с которой до отъезда они были помолвлены. Софья все время была в мыслях Чацкого, во имя ее он осуществил своеобразную инициацию - подобно средневековым рыцарям, мужчинам чести, чей идеал женщины - чистота и святость Богоматери. Софья (как ожидается) не Дева Мария, но и не претендует на эту роль. Она выбирает другого (секретаря своего отца Молчалина), и как бы нам ни казалось странным,что она не оценила Чацкого при его очевидных интеллектуальных достоинствах, все же она недвусмысленно защищает свой выбор со всеми возможными последствиями. Еще любопытнее то, что среда (так называемого „фамусовского общества“) проявляет безупречный инстинкт самосохранения по отношению к Чацкому. Не ясно, оценивает она его ум, в какой степени остается ниже его интеллектуального уровня, но определенно чует серьезную опасность проникновения подобной идеологии в свой строго утвержденный консерватизм, и этой среде удается ловко скомпрометировать приехавшего извне странника типичным „гамлетовским“ ходом: из случайно оброненной Софьей безобидной реплики о его сумасшествии фабрикуется интрига, и эта интрига разрастается до такой степени, что буквально выбрасывает героя из Москвы, тем самым срывая раз и навсегда естественное рецептивное ожидание, что (русская) любовная история закончится хэппи-эндом. Первая интерпретация лишнего человека переворачивает и придает горько-иронический привкус еще одному идиоматичному правилу: у Фамусовых не встречают по одежке, но определенно „провожают“ (отсылают прочь) по уму; это не „горе от ума“, а „горе уму“, которое здесь предупреждено и гарантировано.

По крайней мере еще два десятилетия после „Горя от ума“ драматургия эксплуатирует модель, предложенную Грибоедовым. Первым, кто расширил внутренний 
объем понятия „лишнего“ человека, не только интерпретируя его во множественном числе, но обыгрывая представление о живом и неживом (живое как ненужное / неживое как необходимое) , был Н. В. Гоголь в своем знаменитом романе-поэме „Мертвые души“ (1842). Этой зловещей метафоре долгое время не найдется центрального места на сцене, хотя это вовсе не означает, что она игнорируется театральной практикой. Гоголь актом „детронирования“ героя-аристократа и введением „маленького человека" не столько ставит под сомнение традиции прежней русской литературы, сколько предлагает альтернативу, всматриваясь в поведение массы, в ее оценочную и определяющую реакцию.

Но подобной визии предстоит овладеть литературным мышлением не вдруг, а осторожно и постепенно. До этого возникнет по крайней мере еще одна проекция Чацкого в попытке взять реванш над самодостаточным и самодовольным обществом. Речь идет о Глумове - герое-"шуте" А. Н. Островского из известной комедии „На всякого мудреца довольно простоты" (1868). Уже самое заглавие почти оксюморонно отсылает нас к „Горю от ума“: в нем фигура „умного“ в его превосходной и законченной функции „мудреца“ метафорически эксплицируется. Одновременно, располагаясь между „мудростью“ и „простотой“, заглавие ситуирует казус „умный дурак“ или „глупый умный“, а это, в свою очередь, воспроизводит образ Дурака из фольклорной сказки, которому всегда удается утвердиться над предварительно известным „умником“. В интертекстуальном плане вся „конспиративная" идея Глумова - отменить вынужденную пассивность Чацкого, с этой целью он выбирает более прозорливую стратегию: „перехитрить“ среду. Происходя из не очень состоятельного дворянского рода, но чувствуя в себе достаточно интеллектуальных способностей, герой решает воспользоваться своими „данными", демонстрируя поведение пикаро. Или, выражаясь языком классической драмы, Глумов ставит себя на одну ступень с Чацким в понимании чести и морали, но 
осознает их неприменимость и неуместность, поэтому решается на "разумный компромисс" со своей совестью и подходит к жизни как Хлестаков. Разница одна - если мнимый ревизор Гоголя „случайно“ попадает в известную историю, в которой ориентируется мгновенно и сверхпрагматично, Глумов вполне сознательно изменяет ситуацию в свою пользу.

То, что делает из комедии Островского значимое произведение в контексте интерпретации и раскрытия образа „лишнего человека“, связывает ее непосредственно с повествовательным ходом Тургенева: здесь тоже присутствует дневник, который главный герой систематически ведет. Первоначально автор хотел озаглавить свою пьесу „Дневник, или На всякого мудреца довольно простоты“. Возможность обнаружить и огласить публично интимные откровения персонажа выставляет его дураком в собственных глазах - из дневника окружающие понимают, что он думает о них на самом деле, но, узнав его настоящее мнение, они сами осознают себя дураками, которые так долго велись на его инсинуации. „Я“-документ обнаружен и раскрыт, для нас он важен еще и потому, что доказывает сознательную игру Глумова, его спектакль. Здесь, в отличие от повести Тургенева, дневник представляет собой сборник „режиссерских" заметок, самоанализ, изъясняющий „подтекст" представления. Герой успевает побывать „в ролях“ Молчалина, Скалозуба, Загорецкого, а самом конце даже „надевает костюм“ Чацкого. Он так же уезжает вынужденно, уличенный и выгнанный Мамаевым братством. Но в то время как Чацкий огорчен и унижен, для Глумова подобная развязка ожидаема, это всего лишь вопрос времени, поскольку обман забывшихся „умников" сознателен и хорошо спланирован. Неслучайно одна из его последних реплик, звучащая лейтмотивом в произведении, оспаривает казус „лишний человек“: „Я вам нужен, господа!" (курсив мой - Л. Д.).

Важный акт власти меняет навсегда унаследованное от XIX века и поддерживаемое до конца 50-х годов ста- 
тус-кво и преворачивает радикально общественно-политическую ситуацию. Речь идет о так называемой крестьянской реформе, более известной как отмена крепостного права в России. Это событие становится возможным благодаря подписанию 19 февраля (3 марта) 1861 г. манифеста императором Александром II, после чего его уже именуют „Царем Освободителем“. Это самая крупная социальная реформа, совершившаяся в этом веке, и хотя она была принята неоднозначно - более „против“, чем „за“, факт остается фактом: крепостные получили свое освобождение. Правильно однако пояснить. „Рас-крепощение“ - процесс двумерного естества, как показывает реакция преобладающей части крестьян. С одной стороны, манифестом признается их статус полноценных людей, имеющих равные права с остальными. С другой, достигнутый эффект в известной степени противоположен ожидаемому; освобождается критическая человеческая масса, до того момента сдерживаемая владетелями в рамках строгих правил поведения и контроля: крепостные необразованы, неориентированы, глубоко несамостоятельны, политически безграмотны, они не знают, что делать и куда пойти в новой ситуации. Так, большинство из них впадает в болезненную депрессию: „индульгенция" со свободой 1861 года практически превращает их в ничто, в людей в избытке. Она не интегрирует их, а освобождает накопленную ими энергию, которая в условиях свободы, понимаемой / прочувствованной как незаинтересованность и желание избавиться от них, превращается в негативный поток и жаждет мести (в стране увеличивается криминальный контигент). Словом, начинается внутреннее переструктурирование общества, риск произвола растет, и уже ощущается, что тот момент, когда примитивная масса одержит верх над образованной элитой и сделает попытку силой диктовать условия, не так уж далек.

„Люди в избытке" в литературном смысле - поздняя ипостась (возрождение) мертвых душ. На этом фоне 
драматургия заметит, что при всей пропаганде „демократизации" со снятием формальных ограничений в социуме сохраняется строгая иерархичность в отношениях владелец-слуга, даже в известном смысле еще более ревностно, чем раньше, так как „бывшему“ крепостному уже не гарантирован кров / приют, наоборот - от него ожидается взять на себя ответственность за свои действия. Так что случаи, в которых крестьянин предпочитал сохранить свое прежнее положение, независимо от возможностей волеизъявления, предоставленных ему официально, были не так уж редки. Можно сказать, что в первое десятилетие после реформы эта огромная социальная проблема не только не была решена, а даже болезненно обострилась. И постепенно начавшееся ее „притупление" сопровождалось негативами. Но одна из тенденций такова, что в обществе все более категорически утверждалось пессимистическое ощущение ничтожности жизни. Человек в России начнает лишаться смысла и терять свою предопределенность духовного существа. В этом контексте, например, показательна и более поздняя работа „О назначении человека" (1931) Бердяева, в которой очень остро звучит вопрос о смысле существования.

Как указанные нами процессы отражены драматургией?

Надо сказать, что еще до императорского декрета социальная травестия уже попала в поле зрения театра. Характерная среда, в которой Островский чувствует себя уютнее всего как ее литературный „первооткрыватель" - сословие купцов и мещан, определящих новую русскую мораль, серьезно представлена в его драмах и комедиях, но во всей своей глубине и болезненности перемену покажет не он, покажут более поздние драматурги, ознаменовавшие переход между XIX и XX веками, в канун мятежного 1905-ого и в более далекой перспективе - красного переворота 1917-ого. Речь идет о Чехове, Толстом и Горьком. Одно из многих преимуществ драмы в том, что она имманентно обладает 
двойной визионерской оптикой: во-первых, как текст и во-вторых, - как спектакль. Более того, она обладает способностью „читать“ мир не семантически (в линеарно протекающем сюжете), а семиотически, продуцируя его параллельные реальности и послания. С этой точки зрения, общество в России действительно ассимилирует личность, но она, благодаря памяти и саморефлексии, все еще упорно, насколько это возможно, оберегает и отстаивает свою автономность / аутентичность, чей основной знаковый агент (как это при Чацком) - слово. Точнее, личность в драматургии конца XIX - начала $\mathrm{XX}$ века имеет "право“ однократного действия - уйти, исчезнуть, самоустраниться или приспособиться ценой своей ассимиляции в коллективе. Недосягаемым остается именно ее слово, независимо от того, понимают его или оно оказывается недоступным для среды, в которую попадает. Но так или иначе лишний человек утверждается как необходимый (персонаж) единственно в пространстве драмы.

Может показаться странным то, что из троих упомянутых не дуайен Толстой, а именно Чехов, который был на тридцать два года его моложе, впервые демонстрирует литературный тип „бесполезного“ слабовольного человека и своей интерпретацией закладывает начало, которое продолжится в творчестве остальных двух писателей. На самом деле, они (Толстой и Горький) пишут свои пьесы - „Живой труп“ (1900) и „На дне“ (1902) соответственно - не просто в ответ на чеховские шедевры „Чайка“, „Дядя Ваня“ и „Три сестры“ (созданными между 1895 и 1900), но с намерением их атаковать, оспорить, перечеркнуть, хотя в конечном счете дополняют их, подтверждая их концептуальные открытия. Но сама перекройка "лишнего человека" в новых социокультурных условияй берет свое начало от Чеховского „Иванова“ (1887-1889).

Что же меняется? Для ответа на этот вопрос правильнее всего „послушать" самого драматурга. 30 декабря 1888 г. в пространном письме А. С. Суворину он толкует 
замысел своей пьесы так: „Иванов, дворянин, университетский человек, ничем не замечательный; натура легко возбуждающаяся, горячая, сильно склонная $\mathrm{K}$ увлечениям, честная и прямая, как большинство образованных дворян. [...] Но едва дожил он до 30-35 лет, как начинает уж чувствовать утомление и скуку. [...] Он ищет причин вне и не находит; начинает искать внутри себя и находит одно только неопределенное чувство вины. [...] Такие люди, как Иванов, не решают вопросов, а падают под их тяжестью. Они теряются, разводят руками, нервничают, жалуются, делают глупости и в конце концов, дав волю своим рыхлым, распущенным нервам, теряют под ногами почву и поступают в разряд „надломленных“ и „непонятых“ (Чехов 1978, 12: 312). В процитированных рассуждениях усматривается нечто особо важное. Определяя себя как интеллигента, Иванов самограничивается, сам себя изолирует от психологии общества, отказывается стать массовым человеком, хотя это дополнительно усиливает его роль гравитационного центра для всех. Но его „лишность" в какой-то мере результат волевого акта. А посколько он не вмещается ни в какую конвенцию (тем более при своей снятой ауре разоренного помещика), окружающие его пытаются любой ценой навязать ему поведение согласно воспринятым ими самими социальным стереотипам, точнее, отнестись с пренебрежением к его неординарности/ „шероховатости“. А это, в свою очередь, носитель «обезличивающей» фамилии Иванов предугадывает и сам и принимается неистово искать и обдумывать самый верный выход для себя. Наконец, в этих метаниях приходит к... самоубийству в день своей свадьбы. Здесь угадывается имплицитный диалог с пьесой „Горе от ума“: тогда как у Грибоедова фамусовское общество изолирует Чацкого, предпочитает не замечать его, здесь среда агрессивно пытается подчинить себе чужака, чье мыслящее сознание воспринимает поступки других как намек на ненужность и „невписывание“ его в их среду. Более того - абсурдные 
претензии всех к центральному персонажу предпосылает его рефлексию прийти к той критической точке (одновременность прозрения и забытья), в которой ему удается полностью объективировать мир вокруг себя, о-своить его как свой внутренний, интериоризировать его в своем собственном существе и так одним махом (выстрелом) освободиться от него. Однако выстрел прерывает не просто историю: распадается сам мир-глобус. Иванов возможен без других; но другие не возможны без Иванова, потому что, преследуя его, они превратились в бремя, от которого он твердо решил избавиться. В самом конце неминуемо отдается „цитатное“ гамлетовское молчание.

Заданный Чеховым ракурс превращается в симптоматический для дальнейшего осмысления проблемы: русская драматургия неизменно будет показывать момент падения и / или гибель лишнего человека. И будет подготавливать его саморазрушение, как неизбежность. Разумеется, с соответствующими разновидностями. Но имманентным „узлом“, вокруг которого запутывается и развертывается кризис идентичности у потерпевшего персонажа, является факт, что пренебрежение им, игнорирование, отвержение со стороны другого / других представляет собой проблему для самого (его) существования. Именно в этот момент в художественные дебаты включается Толстой. 27 января 1900 г., через три дня после своего пребывания в Москве, в театре, он пишет в своем дневнике: „Ездил смотреть „Дядю Ваню“ и возмутился. Захотел написать драму „Труп“, набросал конспект" (Толстой 1954, 54: 10). Это предложение хорошо известно, и чаще всего его толкуют как позицию, с которой автор подходит к новой пьесе. Будет поспешным, однако, заключить, что „Живой труп“ - единственно ответ „Дяде Ване“; на самом деле, в своем желании оспорить пьесу Чехова Толстой интегрирует мотивы и из трех объемных драм, написанных им раньше: из „Иванова“, „Чайки“ и „Дяди Вани“; в более поздних редакциях „Трупа“ уже заметны и интертекстуальные переплете- 
ния с пьесой „Три сестры“. Точнее, кажущееся раздражение обнаруживает попадание графа под сильный, по его собственному выражению, „гипноз“ чеховского драматического опуса.

В сущности, что интересует автора „Войны и мира“ в рассматриваемом социальном типе он дает себе отчет о сложном и не особенно приятном, но непредотвратимом процессе: в архетипном конфликте „личность - общество“, „интеллигент - профанная масса“, в котором поднявшейся высоко индивидуальности лишь на короткое время и только до известной степени удается противостоять среде. Пока казус интерпретируется, главным образом, прозе, проблема остается более абстрактной и теоретической - Лермонтов, например, не знает, что Печорин „лишний“; едва когда за нее принимается драматургия, он становится очевидным, динамизируется и перерождается. Толстой констатирует с грустью, что, хотя и сохраняет гибкость ума, русский интеллигент прочно снижает свой социальный статус, опускается и переходит к категории впавшего в немилость, оборванца, подонка общества. По его мнению, „изображение интеллигенции, ее внутренних переживаний, страданий, неудовлетворенности - неблагодарная тема для драмы" (Лакшин 1963: 183). Но до того как Горький сделает очевидным этот факт (проиллюстрирует его) в „На дне“, в „Живом трупе“, мы встречаемся с нигилировавшим самого себя дворянином, о ком вообще нельзя сказать, что он интеллигент.

И все же почему „Дядя Ваня“ перешагивает через порог терпимости графа? Один из возможных ответов, как мне кажется, заложен в типологии сюжетных ядер. Как свидетельствует В. И. Немирович-Данченко, по окончании спектакля высочайший зритель из Ясной Поляны делает следующее импровизированное высказывание: „Что ему еще нужно [Астрову]. Тепло, играет гитара, славно трещит сверчок. А он сначала хотел взять чужую жену, теперь о чем-то мечтает...". И - прибавляет Немирович - неодобрительно кивал головой" (Неми- 
рович-Данченко 1936: 357-358). Как бы он ни был недоволен однако, в „Живом трупе“, как ответная реакция на увиденное, он сам „сделал ставку“ на тот же самый концепт, но каким-то образом перевернутый: чтобы сделать возможным замужество его супруги Лизы с действительным избранником Виктором Карениным, Федор Протасов решает покончить с жизнью, но так на это и не решается, посему покидает свой аристократический дом, уходит к цыганам и живет там с певицей Машей. Лиза, думая, что Федя мертв, выходит замуж за Виктора, но когда выясняется, что ее супруг жив, она обвиняется в двоеженстве и предстает перед судом. Пытаясь оправдать содеянное незнанием, Протасов приходит в суд, чтобы дать показания и чтобы не помешать ее счастью с Карениным (альтернатива: или она должна отказаться от своего второго мужа, или будет сослана в Сибирь), и стреляет в себя. „Хотение чужой жены" и здесь является очень сильным сюжетоопределящим мотивом; необычайно само это добровольное отступление и самоизоляция героя - предпочитая, чтобы его считали мертвым, он потерял свою личность, превратившись в ничто, канул в небытие. Именно в этом состоит инверсия: Войницкий и Соня, оказываясь ненужными в жизни любимых ими людей, в финале делают мучительные усилия начать снова, считая, что так должно быть; в отличие от них Федор не видит смысла жить. Парадокс у Толстого состоит в том, что, продумывая драму в перспективе религиозного опыта и занимая конкретную историю из настоящего случая, его трактовка - ясная и психологически выдержанная - на самом деле, житейски неестественна и художественно вызывающая сомнения; наоборот, целиком придуманный Чеховым казус „Дядя Ваня“ (даже если он и имплицирует какие-то действительно случившиеся события, они подвержены изменениям до неузнаваемости) - захватывающий и убедительный. Захватывающий и убедительный и „Иванов“, с которым „Живой труп" тоже видимо корреспондирует. Более ценен в 
пьесе Толстого абсолютно неожиданный ракурс в отношении „лишнего человека" (все еще в единственном числе). Разумеется, верный своей природе (и своему классу), яснополянский гуру выскажется последним, и вклад его в тему не останется только литературным, но к этому вернусь снова.

В самом конце XIX века на русскую драматическую сцену „заглядывает“ случайный „прохожий“, которого она до такой степени очаровывает, что он решает задержаться на этой сцене как можно дольше, да и то в компании двух своих старших современников, под сильным впечатлением их достижений и подходов. Речь, конечно, идет о Горьком. Он не интеллектуал, как Чехов, и не дворянин, как Толстой; он происходит из нижегородских низов, долго наблюдает за ними и учится у них, пока наконец в 1902 г. не включается в интенсивные дебаты, в которых выступает с позицией, сформулированной в пьесе „На дне“. К его собственному удивлению, пьеса получает всеобщее одобрение, почти восторг, что, конечно, ободряет его неимоверно. На ее премьере 18 декабря того же года в Московском художественном театре публика вызывает автора на бис 15 раз; в прессе мелькают статьи с характеристиками: „настоящая литературная революция“, „апофеоз нового слова и новой литературной мысли“; режиссер Л. А. Сулержицкий ликует: „Ничего подобного еще театр не видел. Ново, сильно, смело, краска яркая, горячая, талант, что называется, брызжет из каждой строчки" (Горький 1970, 7: 613-614). На этом фоне те единственные, от которых Горький не получает восхищения, это... те самые Чехов и Толстой. Первый более чем сдержан. 29 июля он пишет Горькому: „[...] пьесу Вашу я прочел. Она нова и несомненно хороша. [...] Настроение мрачное, тяжкое, публика с непривычки будет уходить из театра, и Вы во всяком случае можете проститься с репутацией оптимиста. [...] Из IV акта Вы увели самых интересных действующих лиц (кроме актера), и глядите теперь, чтобы чего-нибудь не вышло от этого. [...] Смерть актера ужас- 
на; Вы точно в ухо даете зрителю, ни с того ни с сего, не подготовив его. Почему барон попал в ночлежку, почему он есть барон - это тоже недостаточно ясно“ (Чехов. Письма. Электронная версия). Второй, как всегда, прям и язвителен. В поздних своих заметках о нем Горький воссоздает следующий разговор:

„Прочитал ему сцены из пьесы „На дне“; он выслушал внимательно, потом спросил:

- Зачем вы пишете это?

Я объяснил как умел.

[...]

- Старик у вас - несимпатичный, в доброту его - не веришь. Актер - ничего, хорош. [...] Пьесы писать трудно. Проститутка тоже удалась, такие должны быть. Вы видели таких?

- Видел.

- Да, это заметно. Правда дасть себе знать везде. Вы очень много говорите о себе, потому - у вас нет характеров и все люди - на одно лицо. Женщин вы, должно быть, не понимаете, они у вас не удаются, ни одна. Не помнишь их..." (Горький. „Лев Толстой“. Электронная версия).

Независимо от скептицизма Толстого, этим текстом Горький определенно представляет новый ракурс проблемы „лишних людей“. Вернемся на секунду к цитированным уже в самом начале эпиграфам. Если двигаться от „Иванова“ к „На дне“, мы заметим, как всего лишь за приблизительно пятнадцать лет „излишность“ продвигается от индивида к человечеству, охватывая все более крупные массы людей. У среды всегда наготове капканы, в которые неизменно попадают все, кто отличается от массы или ее превосходит.

Хотя заглавие горьковской пьесы создает аллюзию на „вертикальность“, действие размещено вширь и вглубь - направления, симулирающие тупик, но без-донные в психоэмоциональном аспекте. Подобная трехмерность демонстрирует возможности театра - как в намерении, а и в своей необходимости быть новым, он совмещает 
занятые элементы уже существующих образцов и обращается к интертекстуальным реминисценциям. Сам автор в письме к издателю Константину Пятницкому от августа 1902 делится: „В пьесе много лишних людей“ (Горький 1970, 7: 605), имея в виду именно социальный тип. Но не только - в этой пьесе впервые показано роение („размножение“) никому не нужных, превращение их в презренную, низостную толпу, „популяцию“ ничтожеств, коммуну. Хаотический притон „бывших людей“ однако формирует особый „социум“, подчиненный антиправилам порядка и взаимности / сопричастности. В сущности, подобную драматургическую ситуацию первым задает Чехов, и то еще до „Иванова“ - в одноактном этюде „На большой дороге“ (1885), но Горький - тот, кто открывает ее заново и воскрешает ее сообразно с изменившимся политическим контекстом.

С „поднятием занавеса“ мы попадаем в место, официально обозначенное как притон, совмещающее функции пансиона, постоялого двора, сиротского дома, лазарета; иначе говоря, прежнее дворянское имение, в котором чаще всего развертывается действие в русской драматургии (не важно, столичное или провинциальное), исчезает, а если и существует где-то в первообразе, перед нами открывается его метафорическая, обратная сторона - помещение для прислуги. Там собралось все общество, уже освобожденное от формальной иерархии; иерархия сохранена лишь как номинация, но лишена сути, десемантизирована. Так, в одном месте собраны барон, актер, проститутка, вор, слесарь, шапочник, продавщица пельменей, сапожник, два грузчика, скиталец; содержатель и его жена, да еще бог знает кто. Общее ощущение от диалога и хода мыслей каждого в отдельности, подсказывает нам, что жизнь - это нечто, что просто надо перетерпеть. А что касается самой известной и памятной фразы пьесы - реплики Сатина в IV акте: „Чело-век! Это - великолепно! Это звучит... гордо! Че-ло-век!", среди сотен разнообразных и часто противоречащих толкований в контексте моих рассуж- 
дений о лишних людях я бы осмелился предложить еще одно: можно допустить, что имплицитная философия в „На дне“ основывается на монологе Гамлета о человеке, „венце всего живущего“, который, увы, не радует его. Подобный тезис в унисон с органическим (и „унаследованным“) гамлетизмом русской драматургии как раз и переосмысляет шекспировский концепт в условиях все более обезличенной массы. Словно жизнь всех в притоне закончилась, они - постчеловеки - уже в преддверии Ада и ждут своего приговора. Появление старика Луки практически является инфернальным пришествием лже-мессии (Лукавого), который наряду с Сатиным (отсылка к „сатане“) вносит среди обреченных успокаивающее и соблазняющее лжеслово. Странное его исчезновение еще до конца третьего действия в суматохе по поводу убийства содержателя ночлежки Костылева подсказывает возможное его скрытое участие в преступном деянии. Только тогда, когда герои задумываются над его отсутствием, все понимают, что пока Лука был среди них, он размахивал у них под носом моралью, как кукишем, и что он очередной человек, воспользовавшийся их наивностью и растерянностью. Но то, что в действительности мешает злоупотреблять с пьесой „На дне“ в период тоталитаризма - как в России, так и в Болгарии - это факт, что пьеса показывает не „голодных и рабов", а просто отчаявшихся дегенератов всех общественных категорий, потерявших раз и навсегда возможность повторного очеловечивания.

С появлением горьковского текста и триумфальной его постановки во МХAT-е проблема „лишних людей“ как будто достигает своей кульминации, и в дальнейшем вряд ли можно было ожидать чего-нибудь нового на эту тему... пока в очередной - и, увы, в последний раз - снова не вмешался Чехов. „Вишневый сад“ - пьеca, которая подводит своеобразный итог формально закончившемуся столетию и с небольшой, но все же достаточной дистанции, осматривает явление, пытаясь предначертать его будущее. Среди действующих лиц не 
только разорившиеся, потерпевшие крушение в личной жизни и оказавшиеся в психическом коллапсе люди это мы видели и в прежних произведениях драматурга. Интересных, особенных действующих лиц здесь двое: очерчивающийся новый владелец имения с принадлежащим к нему садом, купец Ермолай Лопахин, и престарелый лакей Фирс, бывший крепостной, оставшийся после реформы Александра II добровольно на службе у своих хозяев. Логика драматического действия, как она построена автором, параллельна тому, что происходит в „Горе от ума“. По примеру высокого героя, который, почувствовав себя ненужным и нежеланным у Фамусовых, уезжает, здесь уходит в забытье высшее общество, лишенное собственной своей среды и выгнанное последовательной тактикой сына его недавних слуг. Если взглянуть на сюжет сквозь призму прокомментрованного социального явления, среди прочего можно заметить интересные и провокационные детали. Чехов предсказывает конец не только конкретным героям, но и всему сословию обедневшей аристократии, для которой вряд ли уже найдется место на их родине. Ею все более очевидно овладевают бывшие зависимые, неотесанные, но имеющие большинство и силу „новые русские“, чьи идеалы не вмещаются ни в одной культурной парадигме.

Ненужность общества подсказана очень ярко еще в „На всякого мудреца довольно простоты“, но в пьесе „Вишневый сад“ достигнута возможная граница нетерпимости между отдельными группами, позже названными „классами“. Лопахин более грубый и неуклюжий, чем Глумов, он не такой изысканный, в значительной степени более пассивный. Когда он выигрывает на аукционе сад, никто не встречает его аплодисментами, никто не считает его серьезным владельцем участка, все просто уезжают, ограждая себя от его брутального мещанского поведения. Чужда и неприемлема для них новая философия и организация жизни в России. То, что должно было бы превратиться в событие (покупка 
участка подготавливалась долгое время и представляет собой ожидаемый реванш по отношению к собственникам бывшего зависимого) - скомпрометировано в своей сущности. Они, владельцы, не делали ничего вне рамок закона и порядка. В своем бессилии, однако, Лопахин остро нуждается в образе „врага“ и это активизирует его неимоверно, хотя победа его - самоцель: дорогой, но ничего не стоящий в человеческом плане проект. Врага в лице профессора Серебрякова придумывает самому себе и Войницкий, независимо от того, что его настоящий противник - его собственное малодушие. У Протасова и Фирса нет врагов. Фирс - отрицание Лопахина.

На протяжение всего золотого века русская драматургия сохраняет высокое пространство аристократического духа. Даже в „На дне“, где все вроде бы равны в своей нищете и превратились в подонков общества, заметно сохранившееся в большинстве их внутреннее самоуважение, которое в какой-то момент выводит на поверхность фразу: „Че-ло-век - это звучит гордо!". Если в „Горе от ума“, „Евгении Онегине“ или „Герое нашего времени" „лишний" превосходит остальных, в конце века превосходящий будет замечен среди отвергнутых людей, резко поменявших свой образ жизни. Актер в „На дне“ начинает забывать тексты, которые произносил с успехом, то есть то, что поддерживает его в его сознании как привилегированного / избранного. На пути от „Горя от ума“ к „На дне“ метафора все больше воспринимается буквально, и фраза становится семантически равной самой себе.

Но это явление еще раз заставит вспомнить, что оно все еще живо. Его литературным началом считается дневник тургеневского Чулкатурина, делящийся в своем интимном уединении собственной „излишностью“ в среде, которую обитает. Из-за резонерских интенций подобный прием часто обвиняли в искусственности, преднамеренности и творческом бессилии (по поводу его использования в „На всякого мудреца..." Островский 
тоже подвергается серьезной критике). Но его огромное значение в качестве „предисловия" к действию (своеобразный „гамлетовский“ монолог пишущего перед тем как преобразится в „Дон Кихота“) доказывает не кто иной, как сам Лев Толстой. Его склонность к самостановлению, к записи свои сокровенные размышлений и оценок, приводит его к чему-то более глубокому и невмещающемуся в ограниченный капацитет конвенционального человеческого мышления. В конце своей жизни гений делает величественный - нелитературный, но сильно аллюзивный жест, доказывающий еще и его уровень: осознав себя ненужным и выполнившим свою миссию, он покидает свое собственное имение в Ясной Поляне, странным образом повторяя (воспроизводя) ход Чацкого, с той разницей, что за пределами имения ждет его не карета, а поезд. Именно так ставится точка в развитии данной темы. В лице Толстого Россия теряет последний всемирно признанный моральный авторитет, он становится „лишним“. После него „пещерные“ люди быстро выползут из своих берлог на дне и овладеют страной, надолго (пред)определяя ее облик. Их предводителем, хорошо это или плохо, во многих отношениях будет Горький.

На этом фоне все, что хочется добавить, кажется лишним.

\section{Литература}

ГЕРЦЕН, А. И. Лишние люди и желчевики. В: $\underline{\mathrm{http}} / / /$ gertsen.lit-info.ru/gertsen/public/kolokol-1857-1860/ article-230.htm (Дата доступа: 10 сентября 2020.) ГОРЬКИЙ, М. Пьесы, драматические наброски 1897-1906. Полное собрание сочинений. Художественные произведения в двадцати пяти томах. Т. 7. Москва: Наука, 1970. ГОРЬКИЙ, М. Лев Толстой. B: http://feb-web.ru/feb/tolstoy/ critics/trk/trk-4462.htm?cmd=p (Дата доступа: 10 сентября 2020.) 
ЛАКШИН, В. Я. Лев Толстой и А. Чехов. Москва: Советский писатель, 1963.

НЕМИРОВИЧ-ДАНЧЕНКО, В. И. Из прошлого. Москва-Ленинград: Academia, 1936.

ТОЛСТОЙ, Л. Н. Живой труп. В: http://rvb.ru/tolstoy/01text/ vol_11/01text/0272.htm (Дата доступа: 10 сентября 2020.) ТОЛСТОЙ, Л. Н. Полное собрание сочинения в 90 томах. Том 54. Москва: Художественная литература, 1954.

ЧЕХОВ, А. П. Дневники, записные книжки, отдельные записки 1900-1903. Полное собрание сочинений и писем: $B$ 30т. Т. 12. Пьесы. 1889-1891. Москва: Наука, 1978.

ЧЕХОВ, А. П. Письма. В: http://chehov.niv.ru/chehov/ letters/1902-1903/letter-3797.htm (Дата доступа: 10 сентября 2020.)

Recebido em: 09/04/2020

Aceito em: 19/07/2020

Publicado em setembro de 2020 